\title{
Stability of Cefazolin Sodium in Polypropylene Syringes and Polyvinylchloride Minibags
}

\author{
Ronald F Donnelly
}

\begin{abstract}
Background: Cefazolin is a semisynthetic penicillin derivative with a narrow spectrum of activity covering some gram-positive organisms and a few gram-negative aerobic bacteria.

Objective: To determine the physical and chemical stability of cefazolin sodium reconstituted with sterile water for injection and stored in polypropylene syringes or diluted with either $5 \%$ dextrose in water (D5W) or $0.9 \%$ sodium chloride (normal saline [NS]) and stored in polyvinylchloride (PVC) minibags.
\end{abstract}

Methods: Reconstituted solutions of cefazolin (100 or $200 \mathrm{mg} / \mathrm{mL}$ ) were packaged in polypropylene syringes. More dilute solutions (20 or 40 $\mathrm{mg} / \mathrm{mL}$ ) were prepared in D5W or NS and packaged in PVC minibags. For each concentration-diluent-container combination, 3 containers were designated for each day of analysis (days 7, 14, 21, and 30). Containers were stored under refrigeration $\left(5^{\circ} \mathrm{C}\right)$ with protection from light until the designated day of analysis, at which time one 5-mL sample was collected from each the designated container. The designated containers were then stored at room temperature $\left(21^{\circ} \mathrm{C}\right.$ to $\left.25^{\circ} \mathrm{C}\right)$ with exposure to light for an additional $72 \mathrm{~h}$, and additional samples were drawn. The samples were assayed using a validated, stability-indicating high-performance liquid chromatography method. The colour and clarity of the solutions, as well as their $\mathrm{pH}$, were also monitored on each sampling day.

Results: All samples remained clear for the duration of the study; they had a slight yellow colour that darkened over time, and there was an increase in $\mathrm{pH}$. Solutions diluted with sterile water for injection and stored in polypropylene syringes retained at least $94.5 \%$ of the initial concentration after 30 days of refrigerated storage and at least $92.1 \%$ after an additional $72 \mathrm{~h}$ at room temperature with exposure to light. Samples diluted in D5W or NS and stored in PVC minibags retained at least $95.8 \%$ of the initial concentration after 30 days of refrigerated storage and at least $91.8 \%$ after an additional $72 \mathrm{~h}$ at room temperature with exposure to light.

Conclusions: Cefazolin at various concentrations stored in polypropylene syringes or PVC minibags was stable for up to 30 days with storage at $5^{\circ} \mathrm{C}$ with protection from light, followed by an additional $72 \mathrm{~h}$ at $21^{\circ} \mathrm{C}$ to $25^{\circ} \mathrm{C}$ with exposure to light.

Key words: cefazolin sodium, dextrose, normal saline, polypropylene syringes, polyvinylchloride minibags, stability, high-performance liquid chromatography

\section{RÉSUMÉ}

Contexte : La céfazoline est un dérivé semi-synthétique de la pénicilline à spectre étroit, efficace contre certaines bactéries Gram-positif et quelques bactéries aérobies Gram-négatif.

Objectif : Déterminer la stabilité physique et chimique d'une solution de céfalozine sodique reconstituée dans de l'eau stérile pour injection et conditionnée dans des seringues de polypropylène ou diluée dans du dextrose à $5 \%$ dans l'eau (D5E) ou dans du chlorure de sodium à $0,9 \%$ (solution physiologique salée [SP]) et conditionnée dans des minisacs de polychlorure de vinyle (PVC).

Méthodes : Les solutions reconstituées de céfazoline (100 ou 200 $\mathrm{mg} / \mathrm{mL}$ ) ont été conditionnées dans des seringues de polypropylène. Les solutions plus diluées $(20 \mathrm{mg} / \mathrm{mL}$ ou $40 \mathrm{mg} / \mathrm{mL})$ ont été préparées dans du D5E ou de la SP et conditionnées dans des minisacs de PVC. Pour chacune des combinaisons de concentration, de diluant et de contenant, trois contenants ont été assignés à chaque jour d'analyse (jours 7, 14, 21 et 30). Les contenants ont été réfrigérés $\left(5^{\circ} \mathrm{C}\right)$ à l'abri de la lumière jusqu'au jour choisi pour l'analyse lorsqu'un échantillon de $5 \mathrm{~mL}$ a été prélevé de chacun des contenants désignés. Les contenants désignés ont ensuite été entreposés à la température ambiante $\left(21^{\circ} \mathrm{C}\right.$ à $\left.25^{\circ} \mathrm{C}\right)$ et exposés à la lumière pendant une période additionnelle de 72 heures, puis ils ont été échantillonnés de nouveau. Les échantillons ont été dosés au moyen d'une épreuve validée par chromatographie liquide haute performance. La couleur, la limpidité et le $\mathrm{pH}$ des solutions ont également été contrôlés aux jours de prélèvement des échantillons.

Résultats : Tous les échantillons sont demeurés limpides pendant toute la durée de l'étude; leur couleur jaunâtre a foncé et leur $\mathrm{pH}$ a augmenté dans le temps. Les solutions diluées dans de l'eau stérile pour injection et conditionnées dans des seringues de polypropylène ont conservé au moins $94,5 \%$ de leur concentration initiale pendant 30 jours de réfrigération et au moins $92,1 \%$ pendant 72 heures de plus à la température ambiante sous exposition à la lumière. Les échantillons dilués dans du D5E ou de la SP et conditionnés dans des minisacs de PVC ont conservé au moins $95,8 \%$ de leur concentration initiale après avoir été entreposés pendant 30 jours à une température de $5{ }^{\circ} \mathrm{C}$ et au moins $91,8 \%$ après avoir été entreposés pendant une période additionnelle de 72 heures à la température ambiante et exposés à la lumière.

Conclusions : Les solutions de céfazoline préparées dans une gamme de concentrations et conditionnées dans des seringues de polypropylène ou des minisacs de PVC sont demeurées stables pendant une période maximale de 30 jours après avoir été entreposées à une température de $5{ }^{\circ} \mathrm{C}$, à l'abri de la lumière, suivie d'une période supplémentaire de 72 heures à une température de $21^{\circ} \mathrm{C}$ à $25^{\circ} \mathrm{C}$, exposées à la lumière.

Mots clés : céfazoline sodique, dextrose, solution physiologique salée, seringues de polypropylène, minisacs de polychlorure de vinyle, stabilité, chromatographie liquide haute performance

[Traduction par l'éditeur] 


\section{INTRODUCTION}

$\mathrm{C}$ efazolin sodium, a semisynthetic penicillin derivative, has a narrow spectrum of activity covering some gram-positive organisms and a few gram-negative aerobic bacteria.

Several authors have studied the stability of cefazolin sodium in polyvinylchloride (PVC) bags containing 5\% dextrose in water (D5W), but there are few reports of the stability of this drug prepared in $0.9 \%$ sodium chloride (normal saline [NS]). Dinel and others ${ }^{1}$ performed a quantitative microbiological analysis on solutions packaged in PVC bags and assigned a 24-h expiry period with storage at either room temperature or under refrigeration. Gupta and Stewart ${ }^{2}$ reported that solutions packaged in PVC bags were stable for 5 days at room temperature and $24 \mathrm{~h}$ under refrigeration. Solutions $(10 \mathrm{mg} / \mathrm{mL})$ were stable for $24 \mathrm{~h}$ when stored at $23^{\circ} \mathrm{C}$ after being frozen at $-20^{\circ} \mathrm{C}$ for 30 days. ${ }^{3}$ Similarly, Faouzi and others ${ }^{4}$ found that solutions prepared in $\mathrm{D} 5 \mathrm{~W}$ were stable for $24 \mathrm{~h}$ at room temperature and $48 \mathrm{~h}$ at $4^{\circ} \mathrm{C}$. Cefazolin stored at $4^{\circ} \mathrm{C}$ was stable for 30 days according to analysis by high-performance liquid chromatography (HPLC). ${ }^{5}$ In the only report found in the literature regarding cefazolin sodium diluted in NS $(50 \mathrm{mg} / \mathrm{mL})$, the solution was packaged in plastic syringes and was assigned expiry dates of 22 days with storage at $5^{\circ} \mathrm{C}$ and 7 days with storage at $25^{\circ} \mathrm{C} .^{6}$

This study was undertaken to generate physical compatibility and chemical stability data for cefazolin sodium prepared in D5W, NS, or sterile water for injection after refrigerated storage plus an additional $72 \mathrm{~h}$ storage at room temperature.

\section{METHODS}

\section{Physical Tests}

The $\mathrm{pH}$ of all samples, as described below, was recorded on days $0,7,10,14,17,21,24,30$, and 33 with a calibrated $\mathrm{pH}$ meter (Accumet 25, Fisher Scientific Ltd, Nepean, Ontario). The $\mathrm{pH}$ meter was calibrated before each set of $\mathrm{pH}$ measurements with $\mathrm{pH} 4.00$ and 7.00 buffers.

Colour and clarity were monitored at each sample time under illuminated $4 \times$ magnification. Samples were observed against a black background for particulate matter and against a white background for any change in colour.

\section{Stability Study}

Vials of cefazolin sodium were reconstituted with sterile water for injection to 100 or $200 \mathrm{mg} / \mathrm{mL}$, in accordance with the package insert, ${ }^{7}$ and were then packaged in polypropylene syringes. Stock solution was further diluted with either D5W or NS to prepare solutions of either $20 \mathrm{mg} / \mathrm{mL}$ or $40 \mathrm{mg} / \mathrm{mL}$, which were then packaged in PVC minibags. For each concentration-diluent-container combination, 3 containers were designated for each day of analysis (days 0,7 , 14,21 , and 30). All syringes and minibags were stored at $5^{\circ} \mathrm{C}$ with protection from light up to the designated day of analysis.

On each day of analysis, enough cefazolin reference standard (USP reference material, lot LOC345) was accurately weighed out to prepare a solution of about $1.0 \mathrm{mg} / \mathrm{mL}$ in $\mathrm{pH} 7$ buffer.

On day zero, one 5-mL sample was removed from each container designated for that day and transferred to a clean, dry test tube. These samples were analyzed to determine the initial measured concentration of each concentrationdiluent-container combination. This procedure was repeated on days $7,14,21$, and 30 , using the refrigerated containers designated for those days of analysis. After sample collection on each of these study days, the containers were stored for an additional 72 hours at room temperature $\left(21^{\circ} \mathrm{C}\right.$ to $\left.25^{\circ} \mathrm{C}\right)$ with exposure to light. On days 10,17, 24, and 33, for designated containers that had been stored for $72 \mathrm{~h}$ at room temperature with exposure to light, one $5-\mathrm{mL}$ sample was removed from each container and transferred to a clean, dry test tube. All samples were diluted further and analyzed by HPLC, as described below.

\section{HPLC Assay Chromatographic System}

The chemical assay was conducted according to an HPLC assay method published in the United States Pharmacopeia, 32nd edition. ${ }^{8}$ The column was a $10-\mu \mathrm{m}, 4.6 \times 250 \mathrm{~mm} \mathrm{C18}$ analytical column (Partisil, Phenomenex Inc, Torrance, California; lot 245407). The HPLC system consisted of an isocratic pump (model LC-10AT, Shimadzu Scientific Instruments Inc, Columbia, Maryland), a photodiode array detector (model SDP-M20A, Shimadzu Scientific Instruments Inc) set at $270 \mathrm{~nm}$, and an autoinjector (model Sil-10A $\mathrm{A}_{\mathrm{XL}}$, Shimadzu Scientific Instruments Inc) which injected $50-\mu \mathrm{L}$ samples. The flow rate was set at $1.0 \mathrm{~mL} / \mathrm{min}$. Class-VP software (version 7.1, Shimadzu Scientific Instruments Inc) was used for data collection and analysis.

\section{Assay Validation}

The stability-indicating capacity of the assay was validated for cefazolin by chromatography of samples that had been forcibly degraded by the addition of acid, alkali, an oxidizing agent, or exposure to ultraviolet (UV) light. The acidic sample was prepared by adding 2 drops of concentrated hydrochloric acid to $10 \mathrm{~mL}$ of stock solution $(1 \mathrm{mg} / \mathrm{mL})(\mathrm{pH}$ about 1.6$)$ and letting the mixture stand at room temperature $\left(23^{\circ} \mathrm{C}\right)$. The alkali degradation sample was prepared by adding 3 drops of $5 \mathrm{~N}$ sodium hydroxide to $10 \mathrm{~mL}$ of cefazolin stock solution $(\mathrm{pH}$ about 11.6) and letting the mixture stand at room temperature. 
The oxidized sample was prepared by adding $0.1 \mathrm{~mL}$ of $30 \%$ hydrogen peroxide to $9.9 \mathrm{~mL}$ of cefazolin stock solution $(1$ $\mathrm{mg} / \mathrm{mL})$; this mixture was also kept at room temperature. The fourth degradation sample was generated by exposing the solution to light generated by a UV lamp. The degraded samples were subjected to chromatography to determine if there were any degradation peaks that would interfere with the parent peak.

The linearity of the standard curve for cefazolin was determined over the concentration ranges of 0.021 to 0.206 $\mathrm{mg} / \mathrm{mL}$. Peak purity analysis and chemical identification of the parent compound were performed for all the cefazolin peaks in
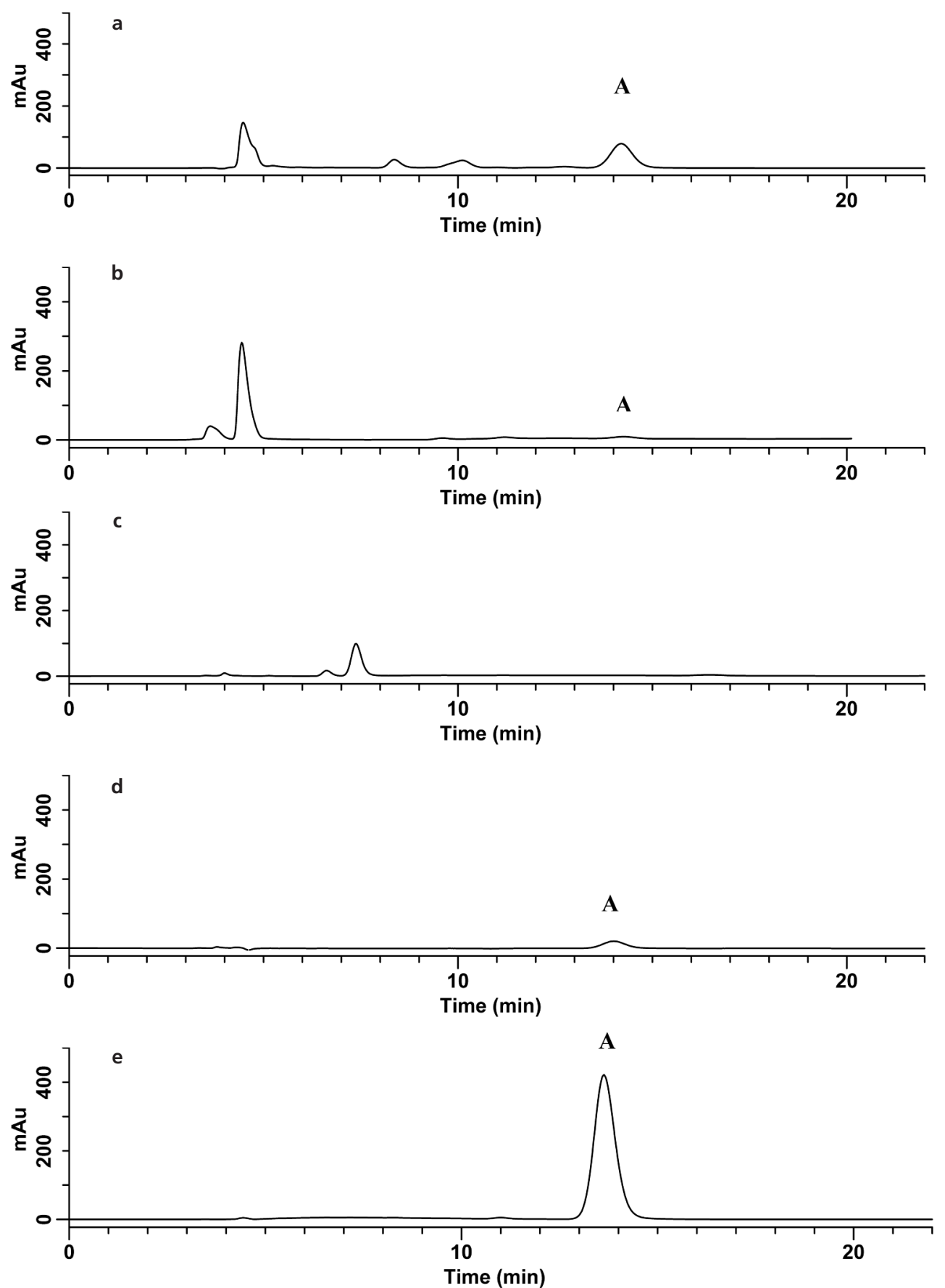

Figure 1. Sample chromatograms of cefazolin sodium and degradation products. a: Cefazolin sample after $125 \mathrm{~h}$ of exposure to acid. b: Alkaline-degraded cefazolin sample after $5 \mathrm{~h}$. c: Oxidized sample of cefazolin after $74 \mathrm{~h}$. d: Cefazolin sample exposed to ultraviolet light for $361 \mathrm{~h}$. e: Cefazolin sample obtained at time zero, before any form of degradation occurred. In all panels, peak A is cefazolin. Au = absorbance units. 
Table 1. Stability of Cefazolin Sodium for Injection

\begin{tabular}{|c|c|c|c|c|c|c|}
\hline \multirow[b]{3}{*}{ Study Day* } & \multicolumn{6}{|c|}{ Storage Conditions; \% of Initial Concentration Remainingt‡ } \\
\hline & \multicolumn{2}{|c|}{ Polypropylene Syringes } & \multicolumn{2}{|c|}{ PVC Minibags } & \multicolumn{2}{|c|}{ PVC Minibags } \\
\hline & $\begin{array}{l}100 \mathrm{mg} / \mathrm{mL} \\
\text { in } \mathrm{H}_{2} \mathrm{O}\end{array}$ & $\begin{array}{c}200 \mathrm{mg} / \mathrm{mL} \\
\text { in } \mathrm{H}_{2} \mathrm{O}\end{array}$ & $\begin{array}{l}20 \mathrm{mg} / \mathrm{mL} \\
\text { in D5W }\end{array}$ & $\begin{array}{l}40 \mathrm{mg} / \mathrm{mL} \\
\text { in D5W }\end{array}$ & $\begin{array}{c}20 \mathrm{mg} / \mathrm{mL} \\
\text { in NS }\end{array}$ & $\begin{array}{c}40 \mathrm{mg} / \mathrm{mL} \\
\text { in NS }\end{array}$ \\
\hline Initial concentration‡ (measured)§ & $96.0 \pm 0.74$ & $194.6 \pm 1.09$ & $17.9 \pm 0.14$ & $35.8 \pm 0.13$ & $18.4 \pm 0.20$ & $36.5 \pm 0.55$ \\
\hline Day 7 & $98.0 \pm 1.5$ & $97.2 \pm 1.5$ & $98.2 \pm 1.7$ & $95.0 \pm 1.0$ & $96.3 \pm 1.0$ & $99.5 \pm 1.2$ \\
\hline Day 10 & $94.6 \pm 1.1$ & $93.4 \pm 0.9$ & $95.3 \pm 0.3$ & $93.4 \pm 0.2$ & $93.4 \pm 0.9$ & $93.0 \pm 1.3$ \\
\hline Day 14 & $98.1 \pm 1.1$ & $99.9 \pm 1.5$ & $101.4 \pm 0.4$ & $102.1 \pm 2.7$ & $101.5 \pm 1.6$ & $100.1 \pm 1.0$ \\
\hline Day 17 & $92.5 \pm 1.3$ & $92.3 \pm 1.3$ & $96.0 \pm 0.6$ & $94.3 \pm 0.5$ & $93.6 \pm 1.8$ & $96.5 \pm 1.3$ \\
\hline Day 21 & $98.6 \pm 0.8$ & $96.9 \pm 0.5$ & $100.3 \pm 0.2$ & $100.2 \pm 0.9$ & $97.2 \pm 2.4$ & $101.2 \pm 0.9$ \\
\hline Day 24 & $94.7 \pm 0.9$ & $92.6 \pm 0.6$ & $95.8 \pm 0.9$ & $94.3 \pm 0.9$ & $92.7 \pm 0.9$ & $94.5 \pm 0.7$ \\
\hline Day 30 & $97.0 \pm 2.3$ & $94.5 \pm 0.4$ & $100.2 \pm 0.6$ & $97.1 \pm 0.5$ & $95.8 \pm 0.4$ & $100.5 \pm 1.3$ \\
\hline Day 33 & $94.4 \pm 0.8$ & $92.1 \pm 0.3$ & $96.2 \pm 1.0$ & $95.6 \pm 1.2$ & $91.8 \pm 0.7$ & $95.2 \pm 0.8$ \\
\hline
\end{tabular}

$\mathrm{D} 5 \mathrm{~W}=5 \%$ dextrose in water, $\mathrm{NS}=$ normal saline $(0.9 \%$ sodium chloride), $\mathrm{PVC}=$ polyvinylchloride, $\mathrm{SD}=$ standard deviation.

* Syringes and minibags were designated for particular days of analysis $\left(0,7,14,21\right.$, and 30 days). Containers were stored at $5^{\circ} \mathrm{C}$, with protection from light, until their assigned date of analysis. After samples for analysis were obtained from designated containers on the date of analysis, the containers were stored for an additional $72 \mathrm{~h}$ at room temperature with exposure to light, at which point additional samples were obtained for analysis (i.e., on days 10, 17, 24, and 33).

tExcept as indicated otherwise.

‡Mean \pm SD $(n=6)$.

$\S$ Measured concentration based on analysis of samples obtained on day zero.

the degradation samples by UV multiwavelength analysis ( 254 and $270 \mathrm{~nm})$ and spectral overlay $(200-350 \mathrm{~nm})$.

Intraday variation was assessed by comparing the average areas of 5 replicate injections at 3 separate time periods and was reported as the coefficient of variation (CV). CV was also used to compare the interday variation of the method on the basis of slopes, linear coefficients, and average areas from 5 separate days. Values from recovery samples obtained on 5 separate days were used to measure the accuracy of the method. The sensitivity of the assay was defined as the concentration that generated a detectable peak while still retaining a linear relationship.

\section{Data and Statistical Analysis}

Relative standard deviation and tailing factors were calculated using USP formulas. The linearity of the standard curve $\left(R^{2}\right)$ was assessed using the least mean squares method.

The results from triplicate samples, assayed in duplicate $(n=6)$, for each concentration-diluent-container combination were averaged. These values were then compared to the day zero value. The data are reported as the percentage of initial concentration remaining \pm standard deviation.

\section{RESULTS}

\section{Physical Tests}

All samples remained clear to the end of the study. There was a slight increase in the yellow colour of the solutions after refrigerated storage with protection from light. Storage at room temperature with exposure to light caused the colour to become more intense. The $\mathrm{pH}$ increased by about $1.0 \mathrm{pH}$ unit, starting from $\mathrm{pH} 5.3$, over the 30 days for containers stored under refrigeration with protection from light. For solutions stored for an additional $72 \mathrm{~h}$ at room temperature with exposure to light, the $\mathrm{pH}$ increased by an additional 1.1 units (starting $\mathrm{pH}$ 5.8).

\section{Chemical Stability Study Assay Validation}

Analysis of the acidic, alkaline, oxidized, and UV-exposed samples indicated the appearance of several new peaks; however, there were no signs of interference with the parent peak (Figure 1). About $20 \%$ of the cefazolin was left after $125 \mathrm{~h}$ exposure to acidic conditions. There was very little starting material (about $1.3 \%)$ left after $5 \mathrm{~h}$ at room temperature under alkaline conditions, and only $3.6 \%$ remained after $74 \mathrm{~h}$ exposure to the oxidizing agent. Long-term exposure (361 h) of cefazolin to UV light caused a deepening of the yellow colour, as well as reduction in concentration to $28.1 \%$. A precipitate formed in the UV-exposed sample, but it was not identified.

The standard curve of cefazolin was linear over the concentrations analyzed. The reproducibility of the assay, measured as the intraday $\mathrm{CV}$, was $1.5 \%$, whereas the interday CVs were $1.2 \%$ (slope), $0.04 \%$ (linearity), and $1.0 \%$ (area ratio). The accuracy of the method was $100.8 \% \pm 1.1 \%$, and the cefazolin sensitivity was $130 \mathrm{ng}$.

All parent peaks from the degradation study were pure, as determined by spectral overlays and UV multiwavelength analysis. Relative standard deviation values were less than $2.0 \%$. 
Tailing factors, determined before the samples were run, were less than 2.0 .

\section{Stability Study}

Data for mean percentage of initial concentration remaining for all time periods are summarized in Table 1. At both concentrations, the solutions diluted with sterile water for injection and packaged in polypropylene syringes were stable for up to 30 days after refrigerated storage with protection from light plus an additional $72 \mathrm{~h}$ at room temperature with exposure to light. Cefazolin at 20 and $40 \mathrm{mg} / \mathrm{mL}$ diluted in either D5W or NS and stored in PVC minibags was stable for up to 30 days under refrigeration with protection from light. The additional storage of previously refrigerated containers at room temperature for $72 \mathrm{~h}$ with exposure to light caused a greater decrease in the concentration of cefazolin; however, the solutions remained above $90 \%$ of the original concentration. The more concentrated solutions in D5W showed a trend for slightly less stability.

\section{DISCUSSION}

All of the degradation samples produced several peaks that eluted faster than cefazolin, some of which were common among all degradation solutions. The alkaline conditions caused the most destruction of cefazolin (1.3\% remaining after $5 \mathrm{~h}$ ). Cefazolin was not as sensitive to acidic conditions or oxidative conditions. Long-term exposure to UV light also caused degradation of the cefazolin.

It was previously reported ${ }^{5}$ that cefazolin $(10 \mathrm{mg} / \mathrm{mL})$ was stable for 30 days when prepared in D5W and stored at $4^{\circ} \mathrm{C}$. The results of the present study confirmed this expiry date for the generic product (Apotex Inc) at concentrations of 20 and $40 \mathrm{mg} / \mathrm{mL}$ and indicated that the drug is stable for an additional $72 \mathrm{~h}$ of storage at room temperature $\left(21^{\circ} \mathrm{C}\right.$ to $\left.25^{\circ} \mathrm{C}\right)$ with exposure to light. The stability of cefazolin diluted in NS was determined to be the same as for cefazolin diluted in D5W. The previously reported expiry date of 22 days for cefazolin diluted to $50 \mathrm{mg} / \mathrm{mL}$ in NS and packaged in polypropylene syringes has been expanded to cover solutions of 100 and 200 $\mathrm{mg} / \mathrm{mL}$ in sterile water for injection and extended to 30 days with refrigerated storage. These solutions were also stable for an additional $72 \mathrm{~h}$ when stored at room temperature with exposure to light. There seemed to be no real difference in stability between the 2 diluents used (D5W and NS). However, the more concentrated solutions in D5W showed a trend toward slightly less stability.

The $\mathrm{pH}$ of the refrigerated solutions was initially about 5.3, increasing over time to above 6.3. After $72 \mathrm{~h}$ storage at room temperature, there was an additional 1.1 increase in $\mathrm{pH}$. The darkening of the yellow colour seemed to correspond with the decrease in concentration of cefazolin.

\section{CONCLUSIONS}

Solutions of cefazolin (100 and $200 \mathrm{mg} / \mathrm{mL}$ ) packaged in polypropylene syringes were stable for up to 30 days with storage at $5^{\circ} \mathrm{C}$ with protection from light (retaining at least $94.5 \%$ of initial concentration) plus an additional $72 \mathrm{~h}$ at $21^{\circ} \mathrm{C}$ to $25^{\circ} \mathrm{C}$ with exposure to light (retaining at least $92.1 \%$ of initial concentration). The potency of both concentrations of cefazolin in either D5W or NS in PVC minibags remained above $95.8 \%$ of the initial concentration with storage at $5^{\circ} \mathrm{C}$ with protection from light and above $91.8 \%$ after an additional $72 \mathrm{~h}$ storage at $21^{\circ} \mathrm{C}$ to $25^{\circ} \mathrm{C}$ with exposure to light.

\section{References}

1. Dinel RA, Ayotte DL, Behme RJ, Black BL, Whitby JL. Comparative stability of antibiotic admixtures in minibags and minibottles. Drug Intell Clin Pharm 1977;11(4): 226-239.

2. Gupta VD, Stewart KR. Quantitation of carbenicillin disodium, cefazolin sodium, cephalothin sodium, nafcillin sodium, and ticarcillin disodium by high-pressure liquid chromatography. J Pharm Sci 1980;69(11): 1264-1267.

3. Holmes CJ, Ausman RK, Walter CW, Kundsin RB. Activity of antibiotic admixtures subjected to different freeze-thaw treatments. Drug Intell Clin Pharm 1980;14(5):353-357.

4. Faouzi MA, Khalfi F, Dine T, Gressier B, Kablan J, Luyckx M et al. Stability and compatibility studies of cefazolin, ceftriaxone, cefotaxime, and latamoxef with PVC infusion bags. Pharmazie 1996;51:963-966.

5. Galanti LM, Hecq JD, Vanbeckbergen D, Jamart J. Long-term stability of cefuroxime and cefazolin sodium in intravenous infusions. J Clin Pharm Ther 1996;21(3):185-189.

6. Gupta VD. Chemical stability of cefazolin sodium after reconstituting in $0.9 \%$ sodium chloride injection and storage in polypropylene syringes for pediatric use. Int J Pharm Compd 2003;7(2):152-154.

7. Cefazolin for injection USP package insert. Toronto (ON): Apotex Inc; 2008 Feb.

8. USP-NF Online [USP 32-NF 27]. Rockville (MD): US Pharmacopeia; [cited 2009 Nov 9]. Available from: www.uspnf.com/uspnf/login. Subscription required to access content.

Ronald F Donnelly, MSc(Chem), BSc(Pharm), is Product Development Pharmacist with the Department of Pharmaceutical Sciences, The Ottawa Hospital (Civic Campus), Ottawa, Ontario.

\section{Address correspondence to:}

Ronald F Donnelly

Department of Pharmaceutical Sciences

The Ottawa Hospital

1053 Carling Avenue

Ottawa ON K1Y 4E9

e-mail: rdonnelly@ottawahospital.on.ca

\section{Acknowledgement}

Apotex Inc provided an unrestricted research grant for this project. The company was not involved in the conduct of the study; the collection, management, or interpretation of the data; or the preparation, review, or approval of the manuscript. 